University of Nebraska - Lincoln

DigitalCommons@University of Nebraska - Lincoln

\title{
Consequences of a short pulse of pesticide exposure for survival and reproduction of Gammarus pulex
}

Anders Cold

Roskilde University

Valery E. Forbes

University of Nebraska-Lincoln, veforbes@umn.edu

Follow this and additional works at: https://digitalcommons.unl.edu/biosciforbes

Cold, Anders and Forbes, Valery E., "Consequences of a short pulse of pesticide exposure for survival and reproduction of Gammarus pulex" (2004). Valery Forbes Publications. 50.

https://digitalcommons.unl.edu/biosciforbes/50

This Article is brought to you for free and open access by the Papers in the Biological Sciences at DigitalCommons@University of Nebraska - Lincoln. It has been accepted for inclusion in Valery Forbes Publications by an authorized administrator of DigitalCommons@University of Nebraska - Lincoln. 


\title{
Consequences of a short pulse of pesticide exposure for survival and reproduction of Gammarus pulex
}

\author{
Anders Cold and Valery E. Forbes \\ Department of Life Sciences and Chemistry, Roskilde University, \\ Universitetsvej 1, P.O. Box 260, 4000 Roskilde, Denmark \\ Corresponding author - A. Cold, tel 45-46-74-27-23, fax 45-46-74-30-11
}

\begin{abstract}
The aim of the present study was to examine the effects of a short and environmentally realistic pulse exposure of different life stages of the freshwater amphipod, Gammarus pulex, to the pyrethroid insecticide, esfenvalerate. We were particularly interested in determining the extent to which detectable effects on key life-history traits persisted following cessation of a brief exposure to this pesticide. Our results indicate that environmentally realistic exposure concentrations of this widely used insecticide can have a significant effect on the survival and reproduction of Gammarus pulex. Comparison of $\mathrm{LC}_{50}$ values indicates that G. pulex has a similar sensitivity to esfenvalerate as the standard test invertebrate, Daphnia magna and is more sensitive than other common stream invertebrates. Despite $100 \%$ survival during pulses of up to $2 \mu \mathrm{g} \mathrm{l}^{-1}$, mortality increased, in some cases markedly, following transfer to clean conditions. Pulse exposure to esfenvalerate at concentrations in the range $0.1-0.6 \mu \mathrm{g}^{-1}$ for as little as $1 \mathrm{~h}$ can have effects on G. pulex survival, pairing behavior, and reproductive output that can still be detected at least 2 weeks following the pulse. Reproductive traits were very sensitive to esfenvalerate, and exposure to $0.05 \mu \mathrm{g} \mathrm{l^{-1 }}$ for $1 \mathrm{~h}$ led to immediate disruption of reproducing pairs, release of eggs or offspring from the brood pouch, and substantial delays in pair formation and subsequent reproduction following transfer to clean water. The kinds of effects on reproductive behavior observed in this study could potentially impact the population dynamics of G. pulex in the field. Whether such effects occur will depend on the frequency, duration, timing, and spatial extent of pesticide exposure in freshwater stream ecosystems, about which relatively little is known. Such information is essential if effects on non-target aquatic species are to be more accurately assessed.
\end{abstract}

Keywords: freshwater invertebrates, life cycles, pyrethroid insecticides, risk assessment

\section{Introduction}

Ecotoxicological tests used to assess the risks of pesticides to non-target aquatic species typically use a minimum exposure period of $24 \mathrm{~h}$ for acute effects assessment (EU, 1991). In addition, the most common tests do not consider effects oc- curring subsequent to the exposure period (Abel and Garner, 1986) and rely largely on standard test species such as Daphnia magna (McCahon and Pascoe, 1988a; Van Leeuwen and Hermens, 1995). Field populations of aquatic organisms, particularly those inhabiting flowing waters, are likely to be exposed to short pulses of pesticide exposure 
following periods of spray drift, surface runoff, or drain flow (Kreuger, 1998; Liess et al., 1999). These pulses may extend anywhere from a few minutes to several hours, depending on the properties of the pesticide and the characteristics of the water body. It is thus of interest to examine how the effects of such more realistic exposure scenarios, including effects that might persist following the end of the pulse, compare with effects predicted from standard risk assessment scenarios.

Pyrethroid insecticides are used widely against a variety of agricultural pests in a range of crops and are recognized as being highly toxic to aquatic invertebrates. Approximately 2 tons of the pyrethroid, esfenvalerate, were sold in Denmark in 2001, which made this pesticide rank fifth in terms of amount sold and second in terms of the area over which it was applied (177,258 ha; MST, 2002). Measured concentrations of esfenvalerate in Danish streams have been detected at concentrations up to $0.66 \mu \mathrm{g} \mathrm{l}^{-1}$ (Aarhus Amt, 1999).

Gammarus pulex is one of the most important invertebrates in northern European streams. Field densities can be up to 20,000-30,000 individuals $\mathrm{m}^{-2}$ (Sand-Jensen and Lindegaard, 1996). As a detritus feeder, G. pulex plays a key role in nutrient cycling in freshwater systems and is an important prey item for many species of fish (Maltby, 1994). Furthermore it plays a central role in the Danish stream quality index system (MST, 1998).

The lifespan of G. pulex is believed to be between 17 and 23 months for females and between 2 and 5 years for males (Welton and Clarke, 1980). Maturity is reached at a body length of approximately $6 \mathrm{~mm}$ (Hynes, 1955), and adults can reach a size of about $12 \mathrm{~mm}$ (females) to $16 \mathrm{~mm}$ (males) (Welton and Clarke, 1980). In the laboratory, female G. pulex can produce between two and five, and up to seven, clutches during their life cycle; each clutch contains an average of 16 eggs (range 10-26) (Welton and Clarke, 1980; McCahon and Pascoe, 1988b). Females are available for mating for only a short period in each reproductive cycle, since mating can only occur shortly after the females' molt (Elwood and Dick, 1990). The reproductive behavior of G. pulex is characterized by a precopulatory guarding phase which plays a key role in the reproductive cycle. The female is carried beneath the male, and the pair swim together for a few days until the female molts, and copulation takes place, normally within a few hours of release of the female's exuvium (Malbouisson et al., 1995). Following fertilization the pairs separate, and the fertilized eggs are carried in a brood pouch on the ventral side of the female until hatching. Thus successful reproduction in this species requires several important steps, any of which potentially may be impaired by pesticide exposure. Previous studies have shown that both precopulatory pairing (Pascoe et al., 1994; Malbouisson et al., 1995) and offspring production (Maltby and Naylor, 1990) may be altered by exposure to toxic chemicals.

The aim of the present study was to examine the effects of a short and environmentally realistic pulse exposure of different life stages of Gammarus pulex to esfenvalerate. We were particularly interested in determining the extent to which detectable effects on key life-history traits persisted following cessation of a brief exposure to this pesticide.

\section{Materials and methods}

\subsection{Collection and maintenance of animals}

Specimens of Gammarus pulex were collected, using a long-handled sieve, from Værebro River, a sediment-rich and slow-running stream (dimensions: $5 \mathrm{~m}$ wide and $1 \mathrm{~m}$ deep) located on the island of Zealand, Denmark. Animals were sorted by hand in the laboratory in water-filled plastic dishes. Only undamaged and active individuals, not infected with parasites (Echinorrhyncus sp.), were selected for experimental use.

In general, maintenance and culturing of the animals followed the descriptions given by McCahon and Pascoe (1988a, 1988b). A minimum of 14 days before the start of any experiment the test animals were stored in 101 culture aquaria, at a density of ca. 200-300 individuals per aquarium. The animals were cultured in aerated water that consisted of a 50:50 mixture of field-sampled freshwater and artificial freshwater. The experiments were conducted using 100\% artificial freshwater. The artificial water was prepared following OECD Guideline 202. Briefly, $29.4 \mathrm{~g} \mathrm{CaCl}_{2} \cdot \mathrm{H}_{2} \mathrm{O}, 12.325 \mathrm{~g}$ $\mathrm{MgSO}_{4} \cdot 7 \mathrm{H}_{2} \mathrm{O}, 6.475 \mathrm{~g} \mathrm{NaHCO}_{3}$ and $0.575 \mathrm{~g} \mathrm{KCl}$ were dissolved in 11 Milli-Q water. This stock solution was diluted $100 \times$ to make the artificial freshwater. 
Both during culturing and experiments animals were maintained at $13{ }^{\circ} \mathrm{C}$ under an artificial light regime (12 h light: $12 \mathrm{~h}$ dark). Food consisted of partly decomposed alder leaves (Alnus sp.) all at the same stage of decay, collected at the sampling site and conditioned in field-sampled water for at least 2 weeks prior to use. In order to minimize turbulence and stress of the test animals during experiments, test chambers were aerated through hypodermic needles as described by Welton and Clarke (1980).

\subsection{General experimental conditions}

With the exception of experiment I, all experiments involved a 1-h pulse exposure of G. pulex to esfenvalerate in water. All exposures were conducted in glass containers, and following the pulse exposure, animals were immediately rinsed and gently transferred to fresh, uncontaminated water. After exposure (except in experiment I) the test chambers consisted of plastic containers (base diameter $=85 \mathrm{~mm}$; top diameter $=$ $75 \mathrm{~mm}$; height $=60 \mathrm{~mm}$ ), holding $200 \mathrm{ml}$ artificial freshwater.

Experiments II and III included treatments with a sediment phase. The sediment consisted of washed gravel with a particle size of 2-3 $\mathrm{mm}$.

Esfenvalerate (i.e., (S)-a-cyano-3phenoxybenzl(S)-2-(4-chlorophenyl)-3methylbutyrate, technical grade $($ HPLC) $=99.9 \%$ ) was obtained from Sigma-Aldrich (Vallensbæk Strand, Denmark) in powder form. Stock solutions were made by dissolving a known weight of esfenvalerate in acetone (technical grade (GC) = 99.8\%). Exposure treatments were made by adding known volumes of stock solution to the water using a microsyringe, followed by mixing. The maximum concentration of acetone in the exposed groups was $300 \mu \mathrm{ll}^{-1}$. Possible solvent effects were examined using a solvent control. Actual concentrations of esfenvalerate were measured in a parallel series of glass containers that did not contain animals or leaf discs but that were otherwise identical to the exposure containers. In all experiments we attempted to minimize losses of esfenvalerate due to absorption to test chamber surfaces by prefilling the test chambers with water of the appropriate concentration for an hour prior to adding the test solutions, after which time the water was replaced with fresh test solution. Unless otherwise noted, all exposure concentrations are given as nominal values.

\subsection{Experiment I: acute (i.e., 24-96 h) toxicity of esfenvalerate to adult Gammarus pulex}

This experiment was conducted in order to estimate standard $\mathrm{LC}_{50}$ values of esfenvalerate $(24,48$ and $96 \mathrm{~h}$ ), for large (10-14 $\mathrm{mm}$ body length) and small (7-8 mm body length) adult G. pulex, so that appropriate exposure concentrations for the pulse experiments could be selected. The nominal test concentrations were $0,0.01,0.05,0.1,0.5,1.0$ and $2.0 \mathrm{\mu g} \mathrm{l}^{-1}$ covering a range of environmentally realistic concentrations (Fyns Amt, 1999; Aarhus Amt, 1999), and the test design was static. Ten individuals in each of three replicates were used per concentration. The test chambers consisted of glass petri dishes containing $120 \mathrm{ml}$ water. Animals were fed daily with leaf discs (diameter $=18 \mathrm{~mm}$ ). Both immobility and mortality were monitored after 1, 24, 48 and $96 \mathrm{~h}$ of exposure. The large adults were exposed as male/female pairs (five pairs per replicate), and additional observations included the number of pairs that were disrupted during or following exposure and whether offspring were released by the females. As it has been reported that G. pulex reaches maturity at $6 \mathrm{~mm}$ (Hynes, 1955), we consider the smaller individuals (7-8 $\mathrm{mm}$ ) to be young adults. However it was not possible to distinguish males from females in animals of this size, and they were therefore randomly assigned in groups of 10 individuals per replicate.

\subsection{Experiment II: effects of pulse exposure on ju- veniles and non-reproducing adults}

In this experiment survival of both juveniles (3-6 $\mathrm{mm}$ body length) and non-reproducing adults (9$15 \mathrm{~mm}$ body length) exposed to a 1-h pulse of esfenvalerate was measured. In addition to a control and acetone control group two exposure groups were used $\left(0.1\right.$ and $\left.0.3 \mu \mathrm{g} \mathrm{l}^{-1}\right)$. In contrast to experiment $\mathrm{I}$, the test chambers also included sediment (one part sediment: five parts water, on a volume basis). In half of the exposure groups the test animals were transferred to clean water and clean sediment after the pulse, whereas in 
the other half the test animals were transferred to chambers in which only the water was changed. The purpose of these additional treatments was to determine the extent to which esfenvalerate bound to sediment particles during the pulse could be subsequently released back into the water column and act as a continued source of exposure. Ten individuals with 10 replicates per concentration were used for adults, whereas five individuals with 10 replicates per concentration were used for juveniles. Following exposure the animals were transferred to test chambers, and survival was observed every second day during a period of 2 weeks.

\subsection{Experiment III: effects of pulse exposure on re- producing pairs and their offspring}

This experiment examined the effect of a short pulse of esfenvalerate exposure on reproductive behavior of adult G. pulex. Fourteen copulatory pairs (replicates) of G. pulex, all with visibly pregnant females were exposed to a 1-h pulse at each of the following concentrations: $0,0.05,0.1$ and 0.3 $\mu \mathrm{g} \mathrm{l}^{-1}$. The exposure procedure was the same as described for experiment II. After exposure each pair was placed in a separate recovery chamber and survival of adults and their offspring were observed for 2 weeks. Juveniles that were released from the adult females both during exposure and during the subsequent period of observation were counted and kept separately. The released offspring were separated from the adults to avoid predation by the adults during the experiment.

\subsection{Experiment IV: effects of pulse exposure on newly released juveniles}

As experiment III revealed a relatively high survival among the offspring released by a previously exposed mother this experiment was conducted to examine sensitivity of newborn juveniles to a pulse exposure of esfenvalerate. Fifty newly released juveniles (5 days old and 1-2 mm long) were exposed to a 1-h pulse at each of the following concentrations: $0,0.05,0.1$, and $0.3 \mu \mathrm{g} \mathrm{l}^{-1}$, and survival was monitored for 1 week. All individuals from each concentration were kept in a single test chamber following exposure. During the observation period the juveniles were fed with fe- cal pellets produced by adults that were collected from the culture aquaria.

\subsection{Experiment V: effects of pulse exposure on pairing behavior and subsequent reproduction}

In contrast to experiment III this experiment was performed with pairs of G. pulex in which the females had not yet been fertilized and therefore were not carrying juveniles. Ten pre-copulatory pairs per treatment were gently separated following the method described by Malbouisson et al. (1995), leaving the pairs on filter paper until the male let go of the female. Males and females were then individually exposed to each of the following concentrations: $0,0.05,0.1,0.3$, and $0.6 \mu \mathrm{g} \mathrm{l}^{-1}$ for $1 \mathrm{~h}$. Body length of the males varied between 10 and $15 \mathrm{~mm}$ whereas the body length of the females varied between 9 and $12 \mathrm{~mm}$. After exposure the animals were rinsed in clean water and placed in test chambers with their original partner. Survival, time elapsed before the pair reformed, and the percent of pairs reforming were observed over a period of 2 weeks. The numbers of juveniles produced per breeding female were also noted. Juveniles and dead animals were immediately removed from the test chambers. Pairs in which one of the partners died following exposure were not used in the final analysis of data.

\subsection{Extraction and analysis of esfenvalerate}

Esfenvalerate was extracted from water following Bonwick et al. (1995) with some modifications. Two grams $\mathrm{NaCl}$ and either 5 or $10 \mathrm{ng}$ of an internal standard $(\lambda$-cyhalothrin; Technical Grade, $99.8 \%$, Sigma-Aldrich, Vallensbæk Strand, DK) were added to a $100 \mathrm{ml}$ water sample in a separation funnel. Subsequently $15 \mathrm{ml}$ of 2,2,4-trimethylpentane (HPLC grade, >99\%, Sigma-Aldrich, Vallensbæk Strand, DK) was added, and the funnel was shaken vigorously for $3 \mathrm{~min}$. The phases were then allowed to separate, and the upper fraction containing the organic phase transferred into a conical flask. The lower fraction was returned to the separation funnel, and the extraction in 10 $\mathrm{ml}$ of 2,2,4-trimethylpentane was repeated twice. The extracts were combined (ca. $35 \mathrm{ml}$ ) and a few grams of $\mathrm{NaSO}_{4}$ were added to remove any residual water. The extract was then filtered (Whatman 
no. 41 filters) and rotary evaporated to dryness. The resulting residue was dissolved in $1 \mathrm{ml}$ hexane, transferred to amber vials, sealed and stored at $-80^{\circ} \mathrm{C}$ until analysis.

Esfenvalerate extracts were analyzed by capillary gas chromatography with electron capture detection (GC-ECD; HP 6890 series gas chromatograph; Agilent G2397A micro electron capture detector). We used four $5 \mu \mathrm{l}$ injections in the splitless mode. The injector of the gas chromatograph was in solvent mode and programmed at an initial temperature of $55^{\circ} \mathrm{C}$ for $1.70 \mathrm{~min}$, which was increased to $300{ }^{\circ} \mathrm{C}$ at a rate of $720{ }^{\circ} \mathrm{C} \mathrm{min}-1$. The oven had an initial temperature of $50{ }^{\circ} \mathrm{C}$, which was increased as follows: increased to $70^{\circ} \mathrm{C}(70$ $\left.{ }^{\circ} \mathrm{C} \mathrm{min}^{-1}\right)$, increased to $115^{\circ} \mathrm{C}\left(60{ }^{\circ} \mathrm{C} \mathrm{min}^{-1}\right)$, increased to $175^{\circ} \mathrm{C}\left(50{ }^{\circ} \mathrm{C} \mathrm{min}{ }^{-1}\right)$, increased to 250 ${ }^{\circ} \mathrm{C}\left(40^{\circ} \mathrm{C} \mathrm{min}^{-1}\right)$, increased to $300^{\circ} \mathrm{C}\left(10^{\circ} \mathrm{C} \mathrm{min}^{-1}\right)$, and held for $5 \mathrm{~min}$. The detector had a temperature of $320^{\circ} \mathrm{C}$. We used a HP 19091S-433 capillary column ( $30 \mathrm{~m} \times 0.25 \mathrm{~mm}$ i.d. $\times 0.25 \mu \mathrm{m}$ HP-5MS), a flow rate of $1.0 \mathrm{ml} \mathrm{min}^{-1}$ with helium as the carrier gas. The detection limit for esfenvalerate with this system was $10 \mathrm{ng} \mathrm{l}^{-1}$.

\subsection{Statistical analyses}

$\mathrm{LC}_{50} \mathrm{~s}$ and their 95\% confidence limits for 24, 48 and $96 \mathrm{~h}$ of exposure (experiment I) were estimated by logistic regression using SYSTATs LOGIT module (SYSTAT ver. 10, SPSS Inc., Chicago).

Survival curves for experiments II-IV were analyzed using the Kaplan-Meier estimator of SYSTATs survival analysis module. This nonparametric estimator allows stratification (e.g., by exposure group, sex or life stage) and can handle censored data (e.g., individuals still alive at the end of the experiment). Survival curves were compared using the Tarone-Ware log-rank test that weights each death by the square root of the total number of individuals at risk, placing less emphasis on deaths occurring later in the experiment. Median survival times were estimated from the calculated survival quantiles and, if necessary, linearly interpolated between sampling days. In experiments II and III, nonparametric Kruskal-Wallis tests were used to compare median numbers of individuals surviving among exposure groups at different times following the pulse exposure.
The Kaplan-Meier technique was used to analyze pairing behavior of adults following pulse exposure (experiment V). The day on which pairs first were observed to re-form was noted for each pair, and the cumulative proportions of reformed pairs calculated for each exposure group.

Reproductive output following exposure was analyzed using Kruskal-Wallis tests, since the data were not normally distributed. Pairwise comparisons were performed manually using the nonparametric version of the Tukey test (Nemenyi test; Zar, 1996, p. 226).

\section{Results}

\subsection{Experiment I: acute (i.e., 24-96 h) toxicity of esfenvalerate to large and small adult Gammarus pulex}

All 30 of the large adults in all exposure groups $\left(0,0.01,0.05,0.1,0.5,1.0\right.$, and $\left.2.0 \mu \mathrm{g} \mathrm{^{-1 }}\right)$ were still alive after $1 \mathrm{~h}$ of exposure to esfenvalerate. In the control 15 out of 15 pairs were still intact whereas only 4 of the 15 pairs remained together in the 0.01 $\mu \mathrm{g} 1^{-1}$ group and no pairs were together at any of the higher concentrations. All of the large adults were still mobile in the control and in the 0.01 and $0.05 \mu \mathrm{g} \mathrm{l^{-1 }}$ groups whereas six individuals were immobile in the $0.1 \mu \mathrm{g} \mathrm{l}^{-1}$ group and all 30 individuals were immobile at all of the higher concentrations. Offspring were released from the females at $0.1 \mu \mathrm{g} \mathrm{^{-1 }}$ and all higher concentrations.

Survival of large adults declined with exposure time between 24 and $48 \mathrm{~h}$ but not between 48 and $96 \mathrm{~h}$ (Table 1). Females seemed somewhat more sensitive than males, and differences were particularly noticeable after $24 \mathrm{~h}$ of exposure (Table 2).

Table 1. $\mathrm{LC}_{50}$ values and their $95 \%$ confidence limits for small $(7-8 \mathrm{~mm})$ and large (10-14 $\mathrm{mm})$ adult Gammarus pulex

\begin{tabular}{llll}
\hline Body size & $\begin{array}{l}\text { Exposure } \\
\text { duration }(\mathrm{h})\end{array}$ & $\begin{array}{l}\mathrm{LC}_{50} \\
\left(\mu \mathrm{g} \mathrm{l}^{-1}\right)\end{array}$ & $\begin{array}{l}95 \% \text { confidence } \\
\text { limits }\end{array}$ \\
\hline Large (10-14 mm) & 24 & 0.340 & $0.308-0.376$ \\
& 48 & 0.142 & $0.131-0.155$ \\
& 96 & 0.132 & $0.122-0.145$ \\
Small (7-8 mm) & 24 & 0.236 & $0.216-0.259$ \\
& 48 & 0.137 & $0.127-0.151$ \\
& 96 & 0.138 & $0.128-0.151$ \\
\hline
\end{tabular}


Table 2. Experiment I: survival, mobility, and pairing behavior of large adult Gammarus pulex exposed to esfenvalerate during $96 \mathrm{~h}$

\begin{tabular}{|c|c|c|c|c|}
\hline $\begin{array}{l}\text { Time } \\
\text { (h) }\end{array}$ & $\begin{array}{l}\text { Concentration } \\
\left(\mu g ~^{-1}\right)\end{array}$ & $\begin{array}{l}\text { Survivors } \\
(\mathrm{M} ; \mathrm{F})\end{array}$ & $\begin{array}{l}\text { Alive but } \\
\text { immobile }\end{array}$ & $\begin{array}{l}\text { Intact } \\
\text { pairs }\end{array}$ \\
\hline \multirow[t]{7}{*}{1} & 0 & $15 ; 15$ & 0 & 15 \\
\hline & 0.01 & $15 ; 15$ & 0 & 4 \\
\hline & 0.05 & $15 ; 15$ & 0 & 0 \\
\hline & 0.1 & $15 ; 15$ & 6 & 0 \\
\hline & 0.5 & $15 ; 15$ & 30 & 0 \\
\hline & 1.0 & $15 ; 15$ & 30 & 0 \\
\hline & 2.0 & $15 ; 15$ & 30 & 0 \\
\hline \multirow[t]{7}{*}{24} & 0 & $15 ; 15$ & 0 & 9 \\
\hline & 0.01 & $15 ; 15$ & 0 & 3 \\
\hline & 0.05 & $15 ; 13$ & 2 & 0 \\
\hline & 0.1 & $13 ; 12$ & 19 & 0 \\
\hline & 0.5 & $10 ; 1$ & 16 & 0 \\
\hline & 1.0 & $6 ; 2$ & 8 & 0 \\
\hline & 2.0 & $0 ; 0$ & - & 0 \\
\hline \multirow[t]{7}{*}{48} & 0 & $15 ; 15$ & 0 & 5 \\
\hline & 0.01 & $15 ; 15$ & 0 & 8 \\
\hline & 0.05 & $14 ; 12$ & 0 & 6 \\
\hline & 0.1 & $12 ; 10$ & 0 & 2 \\
\hline & 0.5 & $2 ; 0$ & 2 & 0 \\
\hline & 1.0 & $0 ; 0$ & - & 0 \\
\hline & 2.0 & $0 ; 0$ & - & 0 \\
\hline \multirow[t]{7}{*}{96} & 0 & $15 ; 15$ & 0 & 5 \\
\hline & 0.01 & $15 ; 15$ & 0 & 8 \\
\hline & 0.05 & $14 ; 11$ & 0 & 7 \\
\hline & 0.1 & $12 ; 9$ & 0 & 6 \\
\hline & 0.5 & $2 ; 0$ & 0 & 0 \\
\hline & 1.0 & $0 ; 0$ & - & 0 \\
\hline & 2.0 & $0 ; 0$ & - & 0 \\
\hline
\end{tabular}

There were five pairs of adults and three replicates exposed per treatment ( $n=30$ per group).

Although they were not counted, the majority of the offspring released during the first hour of exposure were observed to survive in the $0.1 \mu \mathrm{g} \mathrm{l}^{-1}$ treatment, whereas by the end of the experiment most of the offspring released into the $0.5,1.0$ and $2.0 \mu \mathrm{g} \mathrm{l}^{-1}$ groups were dead. In the control, the number of intact pairs was lower after $24 \mathrm{~h}$ and for the remainder of the experiment compared to after $1 \mathrm{~h}$, probably indicating that copulation had taken place (Table 2). In contrast, a number of the pairs in the 0.01 and $0.05 \mu \mathrm{g} \mathrm{l}^{-1}$ groups that were disrupted during the first hour of exposure reformed with increasing exposure time. This was not so in the higher exposure groups.

Survival of small adults as a function of exposure concentration and time showed that, as for the large adults, survival declined between 24 and $48 \mathrm{~h}$ of exposure but not between 48 and 72 or 96 $\mathrm{h}$. The small adults were somewhat more sensitive than the large adults (Table 1). None of the survivors in the $0.5 \mu \mathrm{g} \mathrm{l}^{-1}$ group were active after 24 $\mathrm{h}$ of exposure whereas approximately half of the survivors were active in the $0.1 \mu \mathrm{g}^{-1}$ group and about $75 \%$ of the survivors were active in the 0.05 $\mu \mathrm{g} 1^{-1}$ group.

\subsection{Experiment II: effects of pulse exposure on ju- veniles and non-reproducing adults}

All of the adults survived exposure to $1 \mathrm{~h}$ of esfenvalerate at concentrations up to $0.3 \mu \mathrm{g} \mathrm{l^{-1 }}$. Survival declined with time following the pulse, but differences in median survival among groups were first detectable 7 days following the pulse (KruskalWallis $P$-values were as follows: day 1: 0.746 ; day 2: 0.746; day 3: 0.141; day 4: 0.179 ; day 7: 0.033 ; day 9: 0.005 ; day 11: 0.046; day 14: 0.038 ). Average and median survival times for each group, estimated from the survival curves, are shown in Table 3.

Examination of the survival curves indicated that survival during 14 days following a pulse exposure declined more rapidly in the exposed groups than in the controls and that survival of groups exposed to $0.3 \mu \mathrm{g} \mathrm{l}^{-1}$ declined more rapidly than survival of groups exposed to $0.1 \mu \mathrm{g} \mathrm{^{-1 }}$ (Figure 1a). Although Figure 1 indicates a small difference in survival between groups receiving the same pulse concentration but transferred with or without contaminated sediment, the differences between curves were not significant (TaroneWare; $\left.0.3 \mu \mathrm{g} \mathrm{l}^{-1}: P=0.808 ; 0.1 \mu \mathrm{g} \mathrm{l}^{-1}: P=0.601\right)$. Survival in all groups was high and exceeded $80 \%$ in all treatments (Figure 1a).

All of the juveniles survived exposure to $1 \mathrm{~h}$

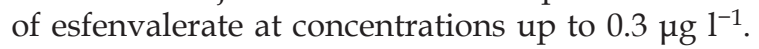
Survival declined with time following the pulse, and in contrast to the adults, differences in median survival among groups were detectable already 1 day following the pulse (Kruskal-Wallis $P$-values were $<0.001$ for all days). Examination of the survival curves indicated that survival during 13 days following a pulse exposure declined more rapidly in the exposed groups than in the controls and that survival of groups exposed to $0.3 \mu \mathrm{g} \mathrm{l}^{-1}$ declined more rapidly than survival of groups exposed to $0.1 \mathrm{\mu g} \mathrm{l}^{-1}$ (Figure 1b). Although Figure 1b indicates 
Table 3. Experiment II: Average and median survival times (days) for juveniles and adults following exposure to a 1-h pulse of esfenvalerate

\begin{tabular}{llll}
\hline Group & $\begin{array}{l}\text { Survival time of juveniles } \\
\text { (average; median) }\end{array}$ & $\begin{array}{l}\text { Survival time of adults } \\
\text { (average; median) }\end{array}$ & $\begin{array}{l}\text { Tarone-Ware, } \chi^{2} \\
\text { and } P \text {-values }\end{array}$ \\
\hline Control & $11.44 ;>13$ & $13.85 ;>14$ & $19.47,0.00001$ \\
Acetone & $11.84 ;>13$ & $13.84 ;>14$ & $19.22,0.00001$ \\
0.1 , contaminated sediment & $5.42 ; 3$ & $13.43 ;>14$ & $117.70,<0.00001$ \\
0.1 , clean sediment & $6.46 ; 4$ & $13.74 ;>14$ & $102.97,<0.00001$ \\
0.3 , contaminated sediment & $1.88 ;<1$ & $13.25 ;>14$ & $163.62,<0.00001$ \\
0.3 , clean sediment & $1.66 ;<1$ & $13.05 ;>14$ & $149.61,<0.00001$ \\
\hline
\end{tabular}

The values in the last column are from comparisons of survival curves (Tarone-Ware log-rank test) between juveniles and adults within each exposure group.

a small difference in survival between groups receiving the same pulse concentration but transferred with or without contaminated sediment, the differences between curves were not signifi-

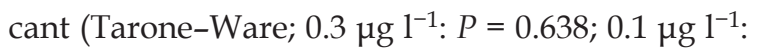
$P=0.184)$. Average and median survival times for each group, estimated from the survival curves, are shown in Table 3. By the end of the experiment
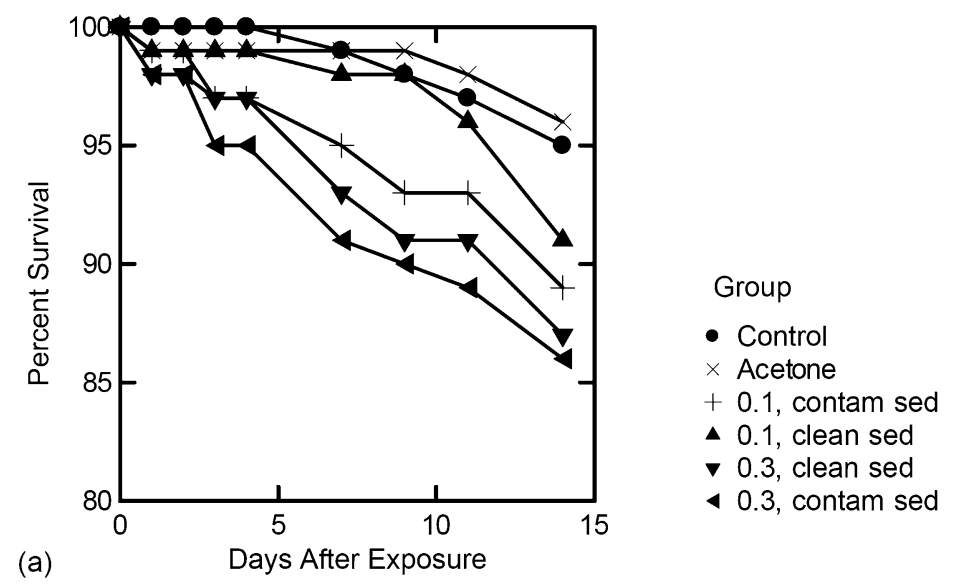

(a)

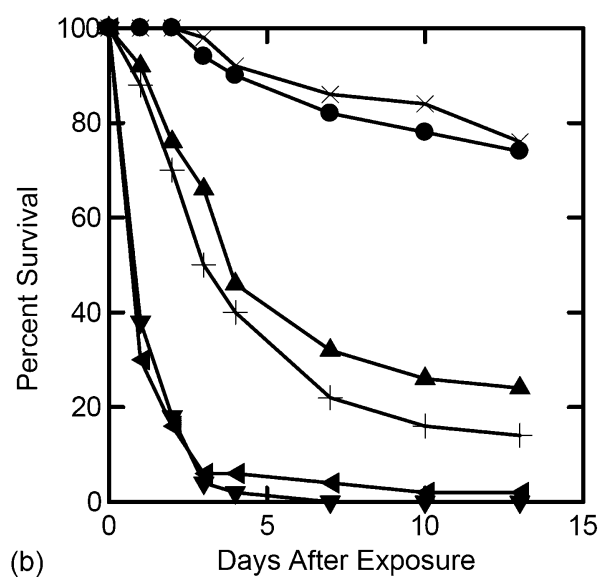

Group

- Control

$\times$ Acetone

+0.1 , contam sed

$\Delta 0.1$, clean sed

$\checkmark 0.3$, clean sed

40.3 , contam sed

(b)

Days After Exposure

Figure 1. Experiment II: survival of G. pulex following a 1-h pulse of esfenvalerate exposure. (a) Non-reproductive adults; (b) juveniles. 
Table 4. Experiment III: effects of pulse exposure on reproducing pairs and their offspring

\begin{tabular}{lllll}
\hline $\begin{array}{l}\text { Concentration } \\
\left(\mu \mathrm{g}^{-1}\right)\end{array}$ & $\begin{array}{l}\text { Number of } \\
\text { offspring released } \\
\text { during pulse }\end{array}$ & $\begin{array}{l}\text { Percentage of } \\
\text { offspring alive } \\
\text { at end of pulse }\end{array}$ & $\begin{array}{l}\text { Number of adults } \\
\text { alive 15 days after } \\
\text { exposure }(\mathrm{F} ; \mathrm{M})\end{array}$ & $\begin{array}{l}\text { Number } \\
\text { of pairs } \\
\text { reformed }\end{array}$ \\
\hline 0 & 12 & 100 & $6 ; 14$ & 11 \\
0.05 & 129 & 89 & $2 ; 7$ & 0 \\
0.1 & 142 & 89 & $3 ; 4$ & 0 \\
0.3 & 114 & 49 & $2 ; 0$ & 0 \\
\hline
\end{tabular}

A total of 14 pairs were exposed per concentration.

survival in the control and acetone control groups was 74 and $76 \%$, respectively, whereas survival in the $0.1 \mu \mathrm{g} \mathrm{l}^{-1}$ groups was 24 (clean sediment) and $14 \%$ (contaminated sediment), and $0 \%$ (clean sediment) and $2 \%$ (contaminated sediment) in the 0.3 $\mu \mathrm{g} 1^{-1}$ groups.

Juvenile survival declined more rapidly compared to adults in all exposure groups, and the differences though smaller, were also significant in the control and acetone control groups (Table 3).

\subsection{Experiment III: effects of pulse exposure on re- producing pairs and their offspring}

During the 1-h pulse exposure, females released large numbers of offspring (Table 4). The percent survival of the released offspring during the pulse declined with esfenvalerate concentration. Survival of the offspring continued to decline with time during 2 weeks in clean water and was dependent on pulse concentration (Figure 2).

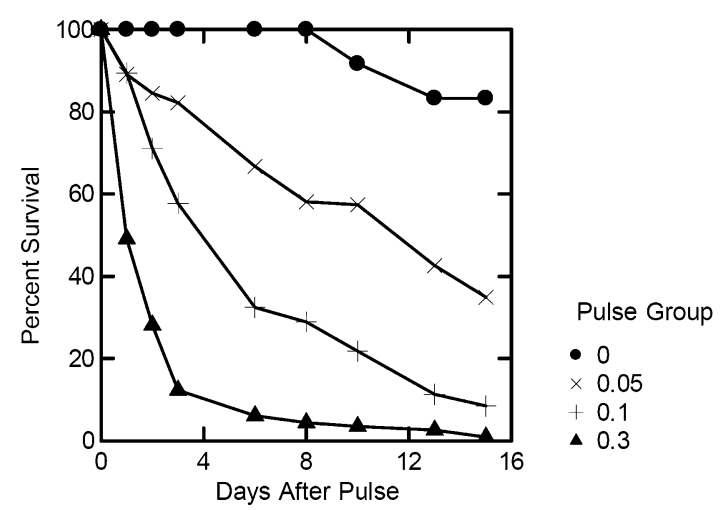

Figure 2. Experiment III: survival of offspring released during a pulse exposure of their parents.
Paired adults were relatively sensitive to esfenvalerate (compared to non-reproducing adults; see experiment I), and survival at the highest concentration $\left(0.3 \mu \mathrm{g} \mathrm{l}^{-1}\right)$ was very low for both males and females (Figure 3). However, even in control treatments the survival of females declined with time and was approximately half that of males by the end of the 2-week experiment (Table 4).

None of the pairs in any of the exposed groups reformed during 2 weeks post-exposure compared to 11 of 14 pairs in the control group (Table 4). Likewise the number of surviving juveniles produced during the 2 weeks following the pulse was substantially reduced in all treatment groups compared to the control (Figure 4).

\subsection{Experiment IV: effects of pulse exposure on newly released juveniles}

Survival of newly released juveniles exposed to a 1-h pulse of esfenvalerate declined with increasing

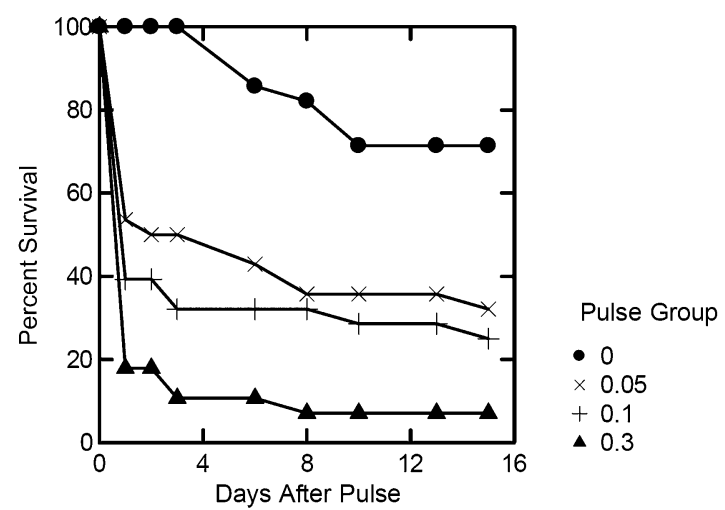

Figure 3. Experiment III: survival of reproducing pairs following a pulse exposure to esfenvalerate. 


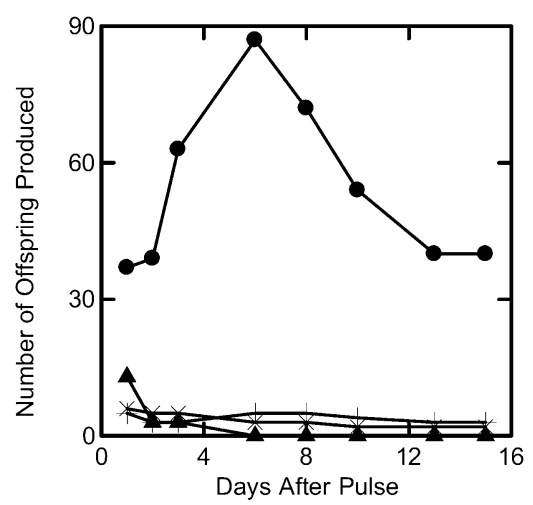

Pulse Group

- 0

$\times 0.05$

$+0.1$

\ 0.3

Figure 4. Experiment III: number of surviving juveniles produced by adults during 2 weeks following a pulse exposure to esfenvalerate.

concentration during a week following the pulse exposure (Tarone-Ware log-rank test, $\chi^{2}=138.2$, $P<0.00001$; Figure 5). Average survival times were: 6.8 day (control), 5.1 day (0.05 $\mu \mathrm{g}^{-1}$ group), 3.5 days $\left(0.1 \mu \mathrm{g} \mathrm{l}^{-1}\right.$ group) and 2.3 day $\left(0.3 \mu \mathrm{g} \mathrm{l^{-1 }}\right.$ group).

\subsection{Experiment V: effects of pulse exposure on re- pairing and subsequent reproduction}

During the 1-h pulse exposure most individuals in the three highest concentrations became immobile and remained on the bottom of the exposure chambers. This effect persisted for several days following exposure. In spite of the relatively large difference in body volume between the sexes, no statistically significant difference in survival

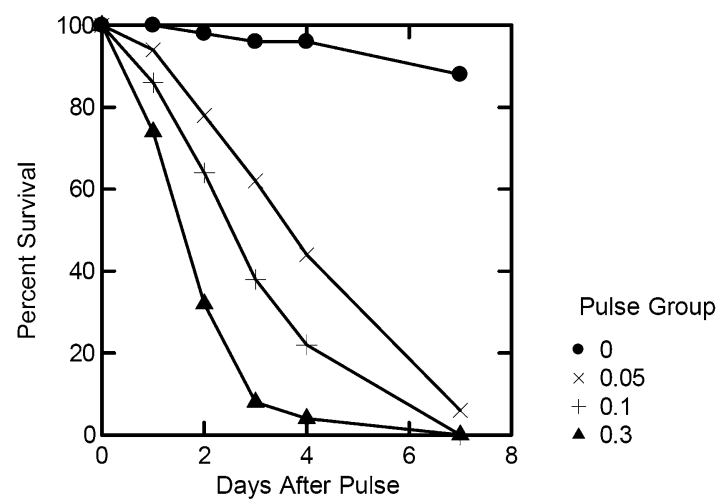

Figure 5. Experiment IV: survival of newly released juveniles during 1 week following a 1-h pulse exposure to esfenvalerate.
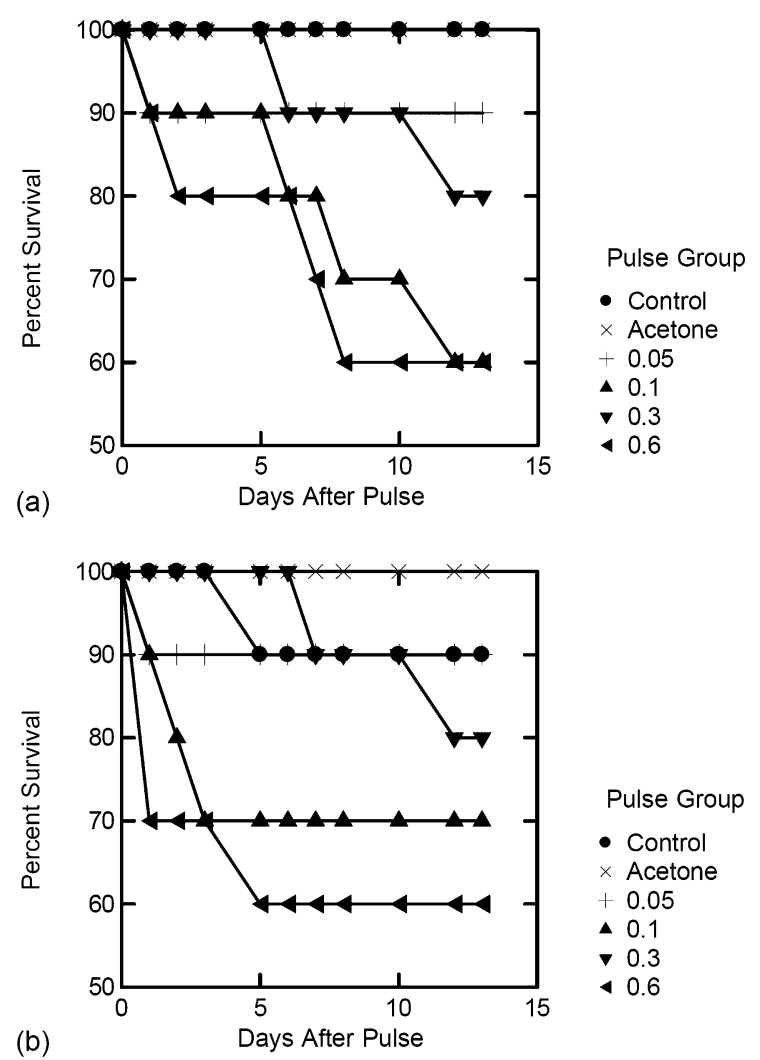

Figure 6. Experiment V: survival of (disrupted) reproducing adults during 2 weeks following a pulse exposure to esfenvalerate. (a) Females; (b) males.

between males and females was detected (TaroneWare log-rank test, $\chi^{2}<0.07, P>0.78$ for all concentrations). Survival 13 days after the pulse exposure was 95 and $100 \%$ in the control and the acetone control, respectively, whereas survival was only $60 \%$ in the highest exposure treatment $\left(0.6 \mu \mathrm{g} \mathrm{l}^{-1}\right)$ (Figure 6). For both sexes the $0.1 \mu \mathrm{g}^{-1}$ group showed a lower survival than the $0.3 \mu \mathrm{g} 1^{-1}$ group. Average survival times were: 17.4 day (control), 13.0 day (acetone), 11.8 days $\left(0.05 \mu \mathrm{g} \mathrm{l^{-1 }}\right), 12.7$ day $\left(0.1 \mu \mathrm{g} \mathrm{l^{-1 }}\right)$, $12.2\left(0.3 \mu \mathrm{g} \mathrm{l}^{-1}\right)$, and 10.9 day $\left(0.6 \mu \mathrm{g} \mathrm{l}^{-1}\right)$.

After only 2 days, $60 \%$ of the surviving pairs in both the control and acetone control groups had re-paired. In contrast, disrupted pairs that were exposed to esfenvalerate took about six times longer (i.e., 12 days) to re-form. Exposure concentration had a significant effect on time to pair re-formation (Tarone-Ware log-rank test, $\chi^{2}=16.29, P=$ 0.006 ), and it should be noted that the times to pair 
Table 5. Experiment V: average time taken for breeding pairs to re-form, percent of females breeding by 13 days following a pulse exposure, and average ( \pm S.D.) number of offspring per breeding female

\begin{tabular}{llll}
\hline $\begin{array}{l}\text { Pulse } \\
\text { group }\end{array}$ & $\begin{array}{l}\text { Average time to } \\
\text { pair re-formation } \\
\text { (days) }\end{array}$ & $\begin{array}{l}\text { Percent of females } \\
\text { reproducing 13 } \\
\text { days after pulse }\end{array}$ & $\begin{array}{l}\text { Average ( } \pm \text { S.D.) } \\
\text { number of offspring } \\
\text { per female }\end{array}$ \\
\hline Control & 4.5 & 80 & $16.1(3.46)$ \\
Acetone & 7.4 & 80 & $13.4(5.59)$ \\
$0.05 \mathrm{\mu g} \mathrm{l}^{-1}$ & 6.9 & 60 & $10(3.03)$ \\
$0.1 \mathrm{gg} \mathrm{l}^{-1}$ & 14.9 & 16.7 & $10(8.49)$ \\
$0.3 \mathrm{\mu g} \mathrm{l}^{-1}$ & 12.2 & 25 & $15(7.21)$ \\
$0.6 \mathrm{\mu g} \mathrm{l}^{-1}$ & 12.3 & 33.3 & $8.5(3.54)$ \\
\hline
\end{tabular}

re-formation for the highest exposure groups were based on fewer individuals, given that survival declined with increasing concentration (Table 5).

Exposure to a pulse of esfenvalerate had a significant effect on the number of juveniles produced during 13 days following the pulse (Figure 7). Esfenvalerate had a highly significant effect on the number of offspring produced following exposure (Kruskal-Wallis test, $P=0.002$ ). The control group produced significantly more offspring than the 0.1 and $0.6 \mu \mathrm{g} \mathrm{l}^{-1}$, but not the $0.3 \mu \mathrm{g} \mathrm{l}^{-1}$ group. However, considering breeding females only, the effect of esfenvalerate on offspring production was marginally significant (Kruskal-Wallis, $P=0.09$ ) indicating that the effect on reproduction was largely to reduce the proportion of females reproducing. The largest number of juveniles (a total of 133

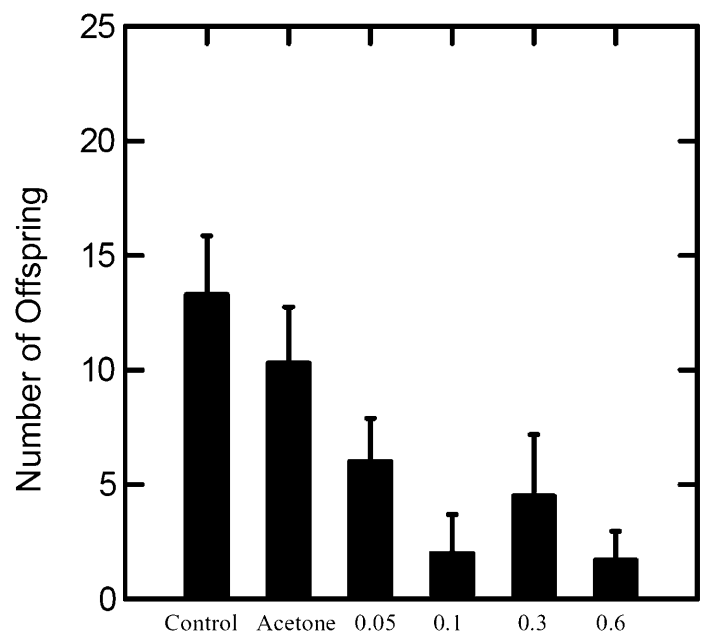

Figure 7. Experiment V: number of offspring produced by pairs of adults that were allowed to re-form following a pulse of esfenvalerate exposure. produced by eight females) was found in the control group and was due to a combination of high survival and rapid re-formation of pairs. In contrast, fewest juveniles were found in the $0.6 \mu \mathrm{g} \mathrm{l}^{-1}$ group (a total of 17 produced by two females). The number of juveniles produced per breeding female varied between 4 (0.1 $\mu \mathrm{g}^{-1}$ group) and 25 (acetone group). It should be noted that the number of juveniles found in each group could be slightly underestimated due to predation by adults.

\subsection{Measured concentrations of esfenvalerate}

Due to various technical problems, we were unable to successfully measure actual exposure concentrations in all experiments. We performed a number of checks of the stock solutions, which were all very close to nominal, and ran several parallel experiments to examine the fate and stability of esfenvalerate in our test systems. In a test system equivalent to those used in experiment I, measured concentrations of a $0.5 \mu \mathrm{g}^{-1}$ nominal treatment were $0.52( \pm 0.007=$ S.D. $)$ at time zero, $0.29( \pm 0.12)$ after $24 \mathrm{~h}, 0.38( \pm 0.03)$ after $48 \mathrm{~h}$, and $0.43( \pm 0.15)$ after $96 \mathrm{~h}$. A test system corresponding to those used in experiments II and III (with and without sediment) and a nominal concentration of $0.2 \mu \mathrm{g} \mathrm{l}^{-1}$ indicated a drop in exposure concentration in the water phase of $20 \%$ during $1 \mathrm{~h}$ in the system without sediment and a drop of $32 \%$ in the system with sediment.

\section{Discussion}

Determining realistic environmental concentrations of pesticides in flowing water bodies is ex- 
tremely difficult. Routine monitoring may miss periods of peak concentrations, and the common approach of pooling samples taken over an extended time period does not allow details of the actual time-varying changes in concentrations to be determined. It has been estimated that between 0.01 and $0.3 \%$ of the applied dosage of pesticides may enter adjacent water bodies, often in connection with rainfall events (Bichel, 1999). In Denmark, at least 32 different pesticides have been detected in streams in recent years, with up to 18 detected in a single stream during the course of a single day (Bichel, 1999).

Liess et al. (1999) performed one of the most temporally fine-grained studies of insecticide contamination of agricultural streams to date. They registered a total of 19 runoff events during a 2 year period in a headwater stream in northern Germany with insecticide contamination detected in the water column 11 times. They were able to link the pesticide inputs with periods of precipitation followed by surface runoff. By using an event-triggered sampling protocol, with a time resolution of up to $1 \mathrm{~h}$, they were able to detect maximum pesticide concentrations of about twice those found in other studies (e.g., they detected up to $6.2 \mu \mathrm{g} \mathrm{l}^{-1}$ for fenvalerate which they compared to a maximum literature value of $3 \mu \mathrm{g} \mathrm{l}^{-1}$ ).

The results of the present study indicate that environmentally realistic exposure concentrations of the widely used pyrethroid insecticide, esfenvalerate, can have a significant effect on the survival and reproduction of G. pulex. Comparison of $\mathrm{LC}_{50}$ values indicates that G. pulex has a similar sensitivity to esfenvalerate as the standard test invertebrate, $D$. magna (juvenile $48 \mathrm{~h}, \mathrm{LC}_{50}=0.27 \mu \mathrm{g} \mathrm{l}^{-1}$, Fairchild et al., 1992), and we have found it to be more sensitive than other common stream invertebrates, such as Asellus aquaticus (48 h, $\mathrm{LC}_{50}=0.69 \mu \mathrm{g} \mathrm{l}^{-1}(95 \% \mathrm{CL}$, $0.58-0.85)$ ), Chironomus riparius ( $48 \mathrm{~h}, \mathrm{LC}_{50}=\mathrm{ca} .2 \mu \mathrm{g}$ $\left.\mathrm{l}^{-1}\right)$, and Bithynia tentaculata $\left(48 \mathrm{~h} \mathrm{LC}_{50}=\gg 10 \mu \mathrm{g} \mathrm{l}^{-1}\right)$, tested under similar exposure conditions in our laboratory (unpublished results).

We found a measurable decline in $\mathrm{LC}_{50}$ between 24 and 48 h of exposure, but not between 48 and 96 $\mathrm{h}$ of exposure. We believe that this is explained by a decline in the actual exposure concentrations in test containers over time, and this is supported by our analytical measurements. We suspect that both adsorption to container walls as well as uptake by animals (the latter of which would reduce exposure concentrations beyond what we measured in parallel containers without animals) were the main processes responsible for the decline, given esfenvalerate's high hydrophobicity $\left(\log K_{\mathrm{ow}}=6.2\right.$ at 25 ${ }^{\circ} \mathrm{C}$, http://www.ace.ace.orst.edu/info/extoxnet/ pips/esfenval.htm). We found measurable declines in the water phase even during $1 \mathrm{~h}$ of exposure, despite attempts to saturate container surfaces prior to addition of test solutions.

There was not a large difference in sensitivity between small and large adult G. pulex in experiment I. Larger differences between adults and juveniles were observed in experiment II where the median survival time of adults following a pulse exposure to $0.1 \mathrm{\mu g} \mathrm{l}^{-1}$ was approximately twice as long as that of juveniles and about six times as long following a pulse exposure to $0.3 \mu \mathrm{g} \mathrm{l^{-1 }}$. Comparison of responses of newly released juveniles (experiment IV) with older juveniles and adults (experiment II) shows that 5 days after experiencing a 1 -h pulse of $0.1 \mathrm{\mu g} \mathrm{l}^{-1}$, nearly $100 \%$ of the adults were still alive (Figure 1a) compared to about $50 \%$ of older juveniles (Figure $1 \mathrm{~b}$ ) and only around $15 \%$ of the few day old juveniles.

Pulse exposure to esfenvalerate at concentrations in the range $0.1-0.6 \mu \mathrm{g}^{-1}$ for as little as $1 \mathrm{~h}$ can have effects on G. pulex survival, pairing behavior, and reproductive output that can still be detected at least 2 weeks following the pulse. Despite $100 \%$ survival during pulses of up to $2 \mu \mathrm{g} \mathrm{^{-1 }}$, mortality increased, in some cases markedly, following transfer to clean conditions. Similar responses have been observed in G. pulex exposed to other toxic chemicals such as cadmium, cyanide, and the pyrethroid permethrin (Abel and Garner, 1986). In the present study, exposure concentrations resulting in effects after only $1 \mathrm{~h}$ are not markedly higher than $96 \mathrm{~h} \mathrm{LC} 50$ values suggesting that the use of standard acute effects endpoints would not overestimate responses to even very brief exposures.

Decreased survival and delays in emergence have also been observed in the caddis fly, Limnephilus lunatus, during several weeks following exposure to a 1-h pulse of fenvalerate (Liess and Schulz, 1996). Although pyrethroids are rapidly metabolized and excreted in warm-blooded vertebrates (Bradbury and Coats, 1982; Hutson and Logan, 1986), the observations of chronic effects following brief periods of pyrethroid exposure in freshwater invertebrates (this study; Abel and 
Garner, 1986; Liess and Schulz, 1996) may reflect a slower metabolism of these compounds by invertebrates or that the damage caused (largely to the nervous system) during the brief period of exposure is to some extent irreversible.

Reproductive traits were very sensitive to esfenvalerate, and exposure to $0.05 \mu \mathrm{g} \mathrm{l^{-1 }}$ for $1 \mathrm{~h}$ led to immediate disruption of reproducing pairs, release of eggs or offspring from the brood pouch, and substantial delays in pair formation and subsequent reproduction following transfer to clean water. Maltby and Naylor (1990) observed an increase in the number of aborted broods and a decrease in viable offspring size in G. pulex females in response to zinc exposure both during and following an exposure period of three to 4 weeks. They attributed these effects to a reduction in the energy available for growth and reproduction, likely to be caused by a reduction in feeding rate in metal exposed females.

In experiments II and III we compared treatments in which only the overlying water or both overlying water and sediment were replaced following the 1-h pulse pesticide exposure. Our use of an entirely inorganic sediment should have enhanced the potential for esfenvalerate to desorb from the sediment surface into the replenished overlying water during the subsequent 2-week observation period. However differences in response between animals for which sediment was or was not replaced following the pulse were not statistically distinguishable. Future experiments will examine how food material exposed to a pulse of pesticide influences feeding and growth of G. pulex maintained in otherwise uncontaminated conditions.

Field studies of the effects of pesticide runoff on natural macrobenthic communities found abundances of G. pulex to be reduced by about $50 \%$ following two runoff events (leading to high concentrations of parathion-ethyl in the stream) (Liess and Schulz, 1999). These authors estimated that it took approximately 6 months for G. pulex to recover to its original density, and comparing this to recovery times of 11 months or more for several of the other stream species investigated, classified G. pulex as 'relatively insensitive' to insecticide contamination.

The kinds of effects on reproductive behavior observed in this study could potentially impact the population dynamics of G. pulex in the field. Delays in reproduction of a few weeks can be especially important in temperate species for which the main reproductive period is seasonally restricted. However, predicting the degree and extent of population-level impacts for any given stretch of stream would require information on the potential for immigration from upstream (unexposed) areas, on the proportion of the stream that was exposed, on the timing of the exposure (relative to G. pulex's life cycle), on potential avoidance reactions (e.g., see Schulz and Liess, 1999), as well as a host of other factors. Relatively little is known about the frequency, duration and spatial extent of pesticide exposure in freshwater stream ecosystems. Such information is essential if effects on non-target aquatic species are to be more accurately assessed.

Acknowledgments - This study was supported by a grant from the Danish Environmental Protection Agency. We are grateful to L. Maarup for excellent technical assistance and to M. Holm for use of unpublished data as well as practical and moral support. We also thank F. Møhlenberg and N. Friberg for valuable feedback and collaboration.

\section{References}

Aarhus, 1999 Aarhus Amt, 1999. Pesticider i vandløb, kilder og søer i Aarhus Amt. Technical Report, Aarhus County, Denmark (in Danish).

Abel and Garner, 1986 P. D. Abel and S. M. Garner, Comparisons of median survival times and median lethal exposure times for Gammarus pulex exposed to cadmium, permethrin and cyanide. Water Res., 20 (1986), pp. 579-582.

Bichel, 1999 Bichel, S., 1999. Rapport fra Underudvalget for Miljø og Sundhed. Miljøstyrelsen, Copenhagen, Denmark, 244 pp. (in Danish).

Bonwick et al., $1995-\mathrm{G}$. A. Bonwick, C. Sun, P. Abdul-Latif, P. J. Baugh, C. J. Smith, R. Armitage, and D. H. Davies, Determination of permethrin and cyfluthrin in water and sediment by gas chromatography-mass spectrometry operated in the negative chemical ionization mode. J. Chromatog. A, 707 (1995), pp. 293-302.

Bradbury and Coats, $1982 \approx$ S. P. Bradbury and J. R. Coats, Toxicity of fenvalerate to bobwhite quail (Colinus virginianus) including brain and liver residues associated with mortality. J. Toxicol. Environ. Health, 10 (1982), pp. 302-319.

Elwood and Dick, $1990 \nleftarrow$ R. W. Elwood and J. T. A. Dick, The amorous Gammarus: the relationship between precopula duration and size-assortative 
mating in G. pulex. Anim. Behav., 39 (1990), pp. 828-833.

EU, $1991-$ EU, 1991. Directive 91/414/EEC concerning the placing of plant protection products on the market. Official Journal Number OJL230, ISSN 03786978. .

Fairchild et al., 1992 J. F. Fairchild, T. W. La Point, J. L. Zajicek, M. K. Nelsen, F. J. Dwyer, and P. A. Lovely, Population-, community- and ecosystemlevel responses of aquatic mesocosms to pulsed doses of a pyrethroid insecticide. Environ. Toxicol. Chem., 11 (1992), pp. 115-129.

Fyns Amt, 1999 Fyns Amt, 1999. Pesticidundersøgelser i vandløb, kildevæld og dræn 1994-1997. Note from Funen County's Nature and Water Department, Denmark (in Danish).

Hutson and Logan, $1986 \nleftarrow$ D. A. Hutson and C. J. Logan, The metabolic fate in rats of the pyrethroid insecticide WL 85871, a mixture of two isomers of cypermethrin. Pest. Sci., 17 (1986), pp. 548-558.

Hynes, 1955 H. B. N. Hynes, The reproductive cycle of some British freshwater Gammaridae. J. Anim. Ecol., 24 (1955), pp. 352-387.

Kreuger, 1998 J. Kreuger, Pesticides in stream water within an agricultural catchment in southern Sweden, 1990-1996. Sci. Tot. Environ., 216 (1998), pp. 227-251.

Liess and Schulz, $1996-$ M. Liess and R. Schulz, Chronic effects of short-term contamination with the pyrethroid insecticide fenvalerate on the caddisfly Limnephilus lunatus. Hydrobiologia, 324 (1996), pp. 99-106.

Liess and Schulz, $1999-$ M. Liess and R. Schulz, Linking insecticide contamination and population response in an agricultural stream. Environ. Toxicol. Chem., 18 (1999), pp. 1948-1955.

Liess et al., 1999 M. Liess, R. Schulz, M. H.-D. Liess, B. Rother, and R. Kreuzig, Determination of insecticide contamination in agricultural headwater streams. Water Res., 33 (1999), pp. 239-247.

Malbouisson et al., $1995 \approx$ J. F. C. Malbouisson, T. W. K. Young, and A. W. Bark, Use of feeding rate and re-pairing of precopulatory Gammarus pulex to assess toxicity of gamma-hexachlorocyclohexane (Lindane). Chemosphere, 30 (1995), pp. 1573-1583.

Maltby, 1994 Maltby, L., 1994. Stress, shredders and streams: Using Gammarus energetics to assess water quality. In: Sutcliffe, D. W., ed., Water Quality and Stress Indicators in Marine and Freshwater Systems: Linking Levels of Organisation. Freshwater Biological Association, Ambleside, UK.

Maltby and Naylor, $1990 \leftarrow$ L. Maltby and C. Naylor, Preliminary observations on the ecological relevance of the Gammarus 'scope for growth' assay: Effect of zinc on reproduction. Funct. Ecol., 4 (1990), pp. 393-397.

McCahon and Pascoe, 1988a C. P. McCahon and D. Pascoe, Culture techniques for three freshwater macroinvertebrate species and their use in toxicity tests. Chemosphere, 17 (1988), pp. 2471-2480.

McCahon and Pascoe, 1988b C. P. McCahon and D. Pascoe, Use of Gammarus pulex (L. ) in safety evaluation tests: Culture and selection of a sensitive life stage. Ecotox. Environ. Saf., 15 (1988), pp. 245-252.

MST, 1998 MST, 1998. Biologisk bedømmelse af vandløbskvalitet. Vejledning fra Miljøstyrelsen No. 5, Copenhagen, Denmark (in Danish).

MST, $2002 \approx$ MST, 2002. Bekæmpelsesmiddelstatistik 2001. Orientering fra Miljøstyrelsen No. 5, Copenhagen, Denmark (in Danish).

Pascoe et al., 1994 D. Pascoe, T. J. Kedwards, S. J. Maund, E. Muthi and E. J. Taylor, Laboratory and field evaluation of a behavioral bioassaythe Gammarus pulex (L. ) precopula separation (GaPPS) test. Water Res., 28 (1994), pp. 369-372.

Sand-Jensen and Lindegaard, 1996 Sand-Jensen, K., Lindegaard, C., 1996. Økologi i Søer og Vandløb, first ed. G. E. C. Gads Publisher, Copenhagen (in Danish).

Schulz and Liess, $1999-\mathrm{R}$. Schulz and M. Liess, Validity and ecological relevance of an active in situ bioassay using Gammarus pulex and Limnephilus lunatus. Environ. Toxicol. Chem., 18 (1999), pp. 2243-2250.

Van Leeuwen and Hermens, $1995 \%$ Van Leeuwen, C. J., Hermens, J. L. M., 1995. Risk Assessment of Chemicals. Kluwer Academic Publishers, Dordrecht.

Welton and Clarke, 1980 J. S. Welton and R. T. Clarke, Laboratory studies on the reproduction and growth of the amphipod, Gammarus pulex (L. ). J. Anim. Ecol., 49 (1980), pp. 581-592.

Zar, 1996 Zar, J. H., 1996. Biostatistical Analysis. Prentice-Hall, London, UK. 